\title{
FAKTOR-FAKTOR YANG MEMPENGARUHI TABUNGAN MUDHARABAH PADA PERBANKAN SYARIAH DI INDONESIA
}

\author{
Sri Rahmany \\ Sekolah Tinggi Ilmu Ekonomi (STIE) Syariah Bengkalis, Riau, Indonesia \\ srirahmanyzahra@gmail.com \\ https://doi.org/10.46367/jps.v1i2.225
}

Received: Mei 11, 2020 Revised: Sep 16, 2020 Accepted: Sep 24, 2020 Published: Oct 12, 2020

\begin{abstract}
The first Islamic bank as a pioneer did not use an interesting system but instead used a profit-sharing system, namely Bank Muamalat Indonesia. The National Sharia Council has issued a fatwa stating that justified savings are savings based on Islamic principles, namely mudharabah and wadiah. The purpose of this research is to determine the effect of policy factors on mudharabah savings transactions in Islamic banking partially and simultaneously. This research uses a quantitative method where the data is in the form of a ratio. The population in this research 34 Islamic banks in Indonesia and were used as samples. The results of the research are statistically proven partially and simultaneously inflation, exchange rates and the BI Rate have a significant effect on mudharabah savings.
\end{abstract}

Keywords: Mudharabah Savings, Inflation, Exchange Rates, BI Rate, Islamic Banking

\section{ABSTRAK}

Bank syariah pertama sebagai pelopor yang tidak menggunakan sistem bunga melainkan menggunakan sistem bagi hasil yaitu Bank Muamalat Indonesia. Dewan Syariah Nasional telah mengeluarkan fatwa yang menyatakan bahwa tabungan yang dibenarkan adalah tabungan yang berdasarkan prinsip Islam yaitu mudharabah dan wadiah. Tujuan penelitian ini adalah untuk mengetahui pengaruh faktor-faktor kebijakan terhadap transaksi tabungan mudharabah pada perbankan syariah secara parsial dan simultan. Penelitian ini menggunakan metode kuantitatif dimana datanya berbentuk rasio. Populasi dalam penelitian ini adalah 34 bank syariah di Indonesia dan sekaligus dijadikan sebagai sampel. Hasil penelitian secara statistik terbukti secara parsial dan simultan inflasi, nilai tukar dan BI Rate mempunyai pengaruh signifikan terhadap tabungan mudharabah.

Kata Kunci: Tabungan Mudharabah, Inflasi, Kurs, BI Rate, Perbankan Syariah

\section{PENDAHULUAN}

Perkembangan perbankan syariah di Indonesia tidak terlepas dari sistem perbankan di Indonesia secara umum. Sistem perbankan syariah yang juga diatur dalam Undang-undang No. 10 tahun 1998 dimana bank umum adalah bank yang 
melaksanakan kegiatan usaha secara konvensional atau berdasarkan prinsip syariah yang kegiatannya memberikan jasa dalam lalu lintas pembayaran. Peran bank syariah dalam memacu pertumbuhan perekonomian daerah semakin strategis dalam rangka mewujudkan struktur perekonomian yang semakin berimbang. Dukungan terhadap pengembangan perbankan syariah juga diperlihatkan dengan adanya "dual banking system", dimana bank konvensional diperkenankan untuk membuka unit usaha syariah.

Salah satu produk yang ditawarkan oleh perbankan syariah adalah dengan menggunakan akad mudharabah. Secara sederhana, pengertian mudharabah adalah teransaksi penanaman dana dari pemilik dana (shahibul maal) kepada pengelola dana (mudharib) untuk melakukan kegiatan usaha tertentu yang sesuai syariah, dengan pengambilan hasil usaha antara kedua belah pihak berdasarkan nisbah yang telah disepakati sebelumnya (Muhammad 2014, 36).

Diantara produk yang menggunakan prinsip bagi hasil dalam penghimpunan dana adalah giro, tabungan dan deposito sebagai salah satu sumber pendanaan bagi operasional bank. Berdasarkan Undang-Undang Nomor 10 tahun 1998 tentang perubahan atas Undang-Undang Nomor 7 tahun 1992 tentang perbankan, yang dimaksud dengan tabungan adalah simpanan yang penarikannya hanya dapat dilakukan menurut syarat tertentu yang disepakati, tetapi tidak dapat ditarik dengan cek, bilyet giro, dan atau alat lainnya yang dipersamakan dengan itu. Adapun yang dimaksud dengan tabungan syariah adalah tabungan yang dijalankan berdasarkan prinsip-prinsip syariah. Dalam hal ini, Dewan Syariah Nasional (DSN) telah mengeluarkan fatwa yang menyatakan bahwa tabungan yang dibenarkan adalah tabungan yang berdasarkan prinsip Islam yaitu mudharabah dan wadiah (Karim 2010, 345).

Besarnya jumlah penduduk yang beragama Islam di Indonesia merupakan salah satu peluang yang besar bagi bank syariah dalam mencapai nasabah sebanyak-banyaknya. Peluang tersebut telah diperkuat oleh adanya fatwa MUI pada Januari 2004 tentang haramnya bunga bank. Dalam menjalankan operasionalnya, terdapat beberapa faktor yang juga membawa pengaruh terhadap keputusan nasabah dalam memilih jasa perbankan khususnya jasa perbankan syariah. Salah satunya adalah inflasi, dimana inflasi merupakan kenaikan hargaharga umum secara terus-menerus dari suatu perekonomian. Apabila terjadi inflasi maka terjadi ketidakpastian kondisi makro ekonomi suatu negara yang mengakibatkan masyarakat lebih menggunakan dananya untuk konsumsi. Tingginya harga dan pendapatan yang tetap atau pendapatan meningkat sesuai dengan besarnya inflasi membuat masyarakat tidak mempunyai kelebihan dana untuk disimpan dalam bentuk tabungan atau diinvestasikan.

Keberadaan bank konvesional dan syariah secara umum memiliki fungsi strategis sebagai lembaga intermediasi dan memberikan jasa dalam lalu lintas pembayaran. Namun karakteristik dari kedua tipe bank (konvensional dan syariah) dapat mempengaruhi perilaku calon nasabah dalam menentukan preferensi mereka terhadap pemilihan antara kedua tipe bank tersebut. Selain itu, pengaruh kondisi perekonomian di Indonesia baik variabel ekonomi makro maupun variabel moneter yang perkembangannya dapat dikendalikan oleh bank sentral juga memiliki andil dalam penyerapan dana masyarakat yang dilakukan oleh perbankan. 
Dengan Market Share (pangsa pasar dibawah $5 \%$ dibanding dengan perbankan konvensional sepertinya perbankan syariah memberikan keraguan bagi pertumbuhan dan perkembangan ekonomi syariah di Indonesia. Meskipun tugas untuk membuktikan bahwa ekonomi syariah sebagai sistem keuangan alternatif, sebenarnya selain terletak dipundak praktisi bank syari'ah dan lembaga keuangan syariah lainnya, dukungan dari berbagai elemen bangsa juga menjadi faktor penentu keberhasilan ekonomi syariah di negara ini. Ekonomi syariah yang diharapkan tumbuh secara signifikan di negara yang mayoritas populasinya muslim ini ternyata menyisakan banyak tanda tanya. Semestinya potensi nasabah emosional yang beragama Islam menjadi peluang tersendiri bagi lembaga keuangan syariah untuk menggenjot kinerja keuangan mereka. Selain itu kebijakan pemerintah dinilai masih setengah hati untuk mendukung secara penuh pertumbuhan lembaga tersebut (Bahri 2016, 27).

Pada tataran makro, nilai uang terhadap barang memiliki peran penting terhadap jumlah tabungan masyarakat di bank. Tingginya inflasi akan menurunkan nilai kekayaan dalam bentuk uang. Inflasi merupakan salah satu peristiwa moneter yang sangat penting dan hampir semua negara mengalaminya baik negara miskin, berkembang atau bahkan negara maju sekalipun tidak dapat lepas dari masalah ini. Apabila terjadi inflasi maka terjadi ketidakpastian kondisi makro ekonomi suatu negara yang mengakibatkan masyarakat lebih menggunakan dananya untuk konsumsi atau investasi dalam bentuk lain, misalnya saja investasi emas. Tingginya harga dan pendapatan yang tetap atau pendapatan meningkat sesuai dengan besarnya inflasi membuat masyarakat tidak mempunyai kelebihan dana untuk disimpan dalam bentuk tabungan atau diinvestasikan.

Faktor lain yang mempengaruhi jumlah tabungan mudharabah adalah nilai kurs rupiah terhadap dollar AS. Secara umum, apabila sesuatu barang ditukar dengan barang lain tentu didalamnya terdapat perbandingan nilai tukar antara keduanya. Nilai tukar itu sebenarnya merupakan semacam harga didalam pertukaran tersebut. Demikian pula pertukaran antara dua mata uang yang berbeda, maka akan terdapat perbandingan nilai atau harga antara kedua mata uang tersebut. Perbandingan nilai inilah yang sering disebut dengan kurs (exchange rate).

Selain itu juga, suku bunga mempunyai peranan yang sangat penting dalam perekonomian, karena suku bunga merupakan salah satu faktor yang dapat mempengaruhi perekonomian secara makro. Suku bunga mencerminkan biaya yang harus dikeluarkan untuk meminjam sejumlah dana serta pendapatan yang diperoleh karena meminjam dana tersebut. Tabungan menurut pandangan ekonomi klasik, merupakan fungsi dari tingkat bunga. Tingkat bunga yang tinggi akan semakin mendorong seseorang untuk menabung dan mengorbankan konsumsi sekarang untuk dimanfaatkan bagi konsumsi di masa yang akan datang. Tentu saja konsep ini berbeda dengan sistem perbankan syariah yang menggunakan sistem bagi hasil atas penggunaan dana oleh pihak peminjam (baik oleh pihak nasabah atau bank).

Tujuan penelitian ini adalah untuk mengetahui pengaruh faktor-faktor kebijakan terhadap transaksi tabungan mudharabah pada perbankan syariah di Indonesia secara parsial dan simultan. 


\section{TELAAH LITERATUR}

\section{Inflasi}

Inflasi adalah kenaikan harga barang-barang yang bersifat umum dan terus-menerus (Rahardja 2008, 359). Secara umum inflasi dapat diartikan sebagai kenaikan tingkat harga secara umum dari barang/komoditas dan jasa selama suatu priode waktu tertentu. Inflasi dapat dianggap sebagi fenomena moneter karena terjadinya penurunan nilai unit penghitungan moneter terhadap suatu komoditas. Sebaliknya, jika yang terjadi adalah penurunan nilai unit penghitungan moneter terhadap barang-barang/komoditas dan jasa didefinisikan sebagai deflasi (deflation) (Karim 2014, 135).

Ada beberapa indikator makroekonomi yang digunakan untuk mengetahui laju inflasi selama suatu periode tertentu, yaitu: a) Indeks harga konsumen (Consumer Price Index), b) Indeks harga perdagangan besar (Wholesale Price Index), c) Indeks harga implisit (GDP Deflator) (Al-Arif 2010, 94).

Menurut para ekonom Islam, inflasi berakibat sangat buruk bagi perekonomian karena: a) Menimbulkan ganguan terhadap fungsi uang, terutama terhadap fungsi tabungan (nilai simpan), fungsi dari pembayaran dimuka, dan fungsi dari unit penghitungan. Orang harus melepaskan diri dari uang dan aset keuangan akibat dari beban inflasi tersebut. Inflasi juga mengakibatkan terjadinya inflasi kembali, atau dengan kata lain "self feeding inflation". b) Melemahkan semangat menabung dan sikap terhadap menabung dari masyarakat (turunnya marginal propensity to save). c) Meningkatkan kecendrungan untuk berbelanja terutama untuk non-primer dan barang-barang mewah (naiknya margginal propensity to consume). d) Mengarahkan investasi pada hal-hal yang nonproduktif yaitu penumpukan kekayaan (hoarding) seperti: tanah, bangunan, logam mulia, mata uang asing dengan mengorbankan investasi kearah produktif seperti: pertanian, industrial. Perdagangan, transportasi, dan lainnya (Karim 2014, 139).

Selain itu, inflasi juga mengakibatkan masalah-masalah yang berhubungan dengan akutansi seperti: a) Apakah penilaian terhadap aset tetap dan aset lancar dilakukan dengan metode biaya historis atau biaya aktual?. b) Pemeliharaan modal riil dengan melakukan isolasi keuntungan inflasioner. c) Inflasi menyebabkan kereksi dan rekonsiliasi operasi (index) untuk mendapatkan kebutuhan perbandingan waktu dan tempat (Karim 2014, 139).

Inflasi merupakan peningkatan harga-harga secara umum dan terus menerus. Apabila terjadi inflasi maka terjadi ketidakpastian kondisi makro ekonomi suatu negara, adanya ketidak pastian kondisi perekonomian suatu negara akan mengakibatkan masyarakat lebih menggunakan dananya untuk konsumsi. Tingginya harga dan pendapatan yang tetap atau pendapatan meningkat sesuai dengan besarnya inflasi membuat masyarakat tidak mempunyai kelebihan dana untuk disimpan atau diinvestasikan (Suharyanti 2010, 74).

\section{Nilai Tukar (Kurs)}

Kurs valuta asing atau nilai tukar didefinisikan sebagai jumlah uang domestik yang dibutuhkan, yaitu banyaknya rupiah yang dibutuhkan untuk memperoleh satu unit mata uang asing (Sukirno 2011, 397). Kurs (nilai tukar) valuta asing juga dapat diartikan sebagai harga mata uang negara asing dalam satuan mata uang domestik. 
Exchange rate (nilai tukar) atau yang lebih populer dikenal dengan nama kurs mata uang adalah catatan (quotation) harga pasar dari mata uang asing (foreign currency) dalam harga mata uang domestik (domestic currency), begitu pula sebaliknya, yaitu harga mata uang domestik dalam mata uang asing (Al-Arif 2010, 107). Nilai tukar uang menggambarkan tingkat harga pertukaran dari satu mata uang ke mata uang yang lainnya dan digunakan dalam berbagai transaksi, antara lain transaksi perdagangan internasional, ataupun aturan uang jangka pendek antar negara yang melewati batas-batas geografis ataupun batas-batas hukum.

Nilai tukar suatu mata uang dapat ditentukan oleh pemerintah (otoritas moneter) seperti pada negara-negara yang memakai sistem fixed exchange rates ataupun ditentukan oleh kombinasi antara kekuatan-kekuatan pasar yang saling berinteraksi (bank komersial, perusahaan multinasional, perusahaan manajemen aset, perusahaan asuransi, bank devisa, bank sentral) serta kebijakan pemerintah seperti negara-negara yang memakai rezim sistem "flexible exchange rates" (Karim 2014, 157).

Mata uang asing dapat digunakan untuk membeli barang-barang dari luar negeri ataupun juga asetfinansial seperti saham, obligasi, treasury bills, options, futures, warrants, dan lain-lain. Untuk kemudahan analisis, akan diasumsikan hanya ada dua negara yang melakukan perdagangan internasional yaitu domestik dan asing. Sejarah mencatat, dalam sistem moneter Internasional pernah dikenal tiga macam sistem nilai tukar mata uang (kurs valas). Tiga sistem tersebut adalah: a) Sistem nilai tukar tetap (fixed exchange rate system), b) Sistem nilai tukar mengambang (floating exchange rate system), Sistem nilai tukar yang dikaitkan (pagged exchange rate system) (Al-Arif 2010, 111-116).

Perubahan dalam permintaan dan penawaran suatu valuta, yang selanjutnya menyebabkan perubahan dalam kurs valuta, disebabkan oleh banyak faktor. Yang terpenting diantaranya adalah sebagai berikut: a) Perubahan dalam citarasa masyarakat, b) Perubahan harga baran ekspor dan impor, c) Kenaikan harga umum (inflasi), d) Perubahan suku bunga dan tingkat pengembalian investasi (Sukirno 2011, 417).

Kurs merupakan faktor eksternal (luar) yang juga mempengaruhi jumlah dana pihak ketiga. Melemahnya nilai tukar rupiah terhadap dollar AS, mencerminkan kondisi perekonomian yang tidak menentu sehingga meningkatkan risiko berusaha yang akan direspon oleh dunia usaha dengan menitipkan uangnya pada bank syariah. Nilai tukar rupiah terhadap dollar AS diduga mempunyai pengaruh terhadap perkembangan dana pihak ketiga bank syariah termasuk didalamnya tabungan mudharabah. Dana pihak ketiga perbankan syariah sensitif terhadap fluktuasi nilai tukar rupiah. Dan kecenderungan meningkatnya dana pihak ketiga sejalan dengan kecenderungan menguatnya nilai tukar rupiah terhadap US Dollar. Sebaliknya ketika menurunnya nilai tukar Rupiah terhadap US Dollar, mencerminkan stabilitas perekonomian yang semakin menurun akan risiko dalam menjalankan usahanya, sehingga para investor yang sebelumnya menanamkan modalnya ke pasar uang beralih ke dunia perbankan. Dengan menyimpan sebagian modalnya di produk penghimpunan dana khususnya dalam hal ini tabungan mudharabah (Ariestya 2011, 40). 


\section{BI Rate}

Menurut Bank Indonesia BI rate adalah suku bunga kebijakan yang mencerminkan sikap atau stance kebijakan moneter yang ditetapkan oleh Bank Indonesia dan diumumkan kepada publik. BI rate merupakan indikasi suku bunga jangka pendek yang diinginkan Bank Indonesia dalam upaya mencapai target inflasi. BI rate digunakan sebagai acuan dalam operasi moneter untuk mengarahkan agar suku bunga Sertifikat Bank Indonesia (SBI) 1 bulan hasil lelang operasi pasar terbuka berada disekitar BI rate. Selanjutnya suku bunga BI diharapkan mempengaruhi Pasar Uang Antar Bank (PUAB), suku bunga pinjaman, dan suku bunga lainnya dalam jangka panjang. BI rate diumumkan oleh dewan gubernur Bank Indonesia setiap rapat dewan gubernur bulanan dan diimplementasikan pada operasi moneter yang dilakukan Bank Indonesia melalui pengelolaan likuiditas (liquidity management) di pasar uang untuk mencapai sasaran operasional kebijakan moneter.

Penetapan respons (stance) kebijakan moneter dilakukan setiap bulan melalui mekanisme RDG (Rapat Dewan Gubernur) bulanan dengan cakupan materi bulanan. Respon kebijakan moneter dinyatakan dalam perubahan BI Rate (secara konsisten dan bertahap dalam kelipatan 25 basis poin (bps). Dalam kondisi untuk menunjukkan intensi Bank Indonesia yang lebih besar terhadap pencapaian sasaran inflasi, maka perubahan BI Rate dapat dilakukan lebih dari 25 bps dalam kelipatan 25 bps.

\section{Tabungan Mudharabah}

Tabungan adalah simpanan yang penarikannya hanya dapat dilakukan menurut syarat tertentu yang disepakati, tetapi tidak dapat ditarik dengan cek/bilyet giro, dan/atau alat lainnya yang dipersamakan dengan itu (Muhammad 2014, 35). Tabungan juga diartikan sebagai salah satu bentuk simpanan (funding) yang dananya disimpan pada suatu rekening yang setiap saat dan kapan saja pemilik tabungan dapat menarik uangnya baik tunai maupun nontunai (pindah buku, transfer ke bank lain) melauli mesin ATM atu teller (Supriyono 2011, 24).

Menurut Hermansyah, tabungan diartikan sebagai simpanan pihak ketiga pada bank yang penarikannya dapat dilakukan menurut syarat-syarat tertentu (Hermansyah 2011, 48). Dalam litelatur lain tabungan didefinisikan sebagai simpanan yang penarikannya hanya dapat dilakukan dengan syarat tertentu yang disepakati, dan tidak dengan cek atau bilyet giro atau alat lain yang dapat dipersamakan dengan itu.

Berdasarkan Undang-Undang No 21 tahun 2008 tentang perbankan syariah, tabungan adalah simpanan berdasarkan akad wadi'ah atau investasi dana berdasarkan akad mudharabah atau akad lain yang tidak bertentangan dengan prinsip syariah yang penarikannya hanya dapat dilakukan menurut syarat dan ketentuan tertentu yang disepakati, tetapi tidak dapat ditarik dengan cek, bilyet giro, dan/atau alat lainnya yang dipersamakan dengan itu.

Tabungan syariah adalah tabungan yang dijalankan berdasarkan prinsipprinsip syariah. Dalam hal ini, Dewan Syariah Nasional (DSN) telah mengeluarkan fatwa yang menyatakan bahwa tabungan yang dibenarkan adalah tabungan yang berdasarkan prinsip wadiah dan mudharabah (Karim 2010, 357). Menabung merupakan tindakan yang dianjurkan oleh Islam, karena dengan menabung berarti seorang muslim mempersiapkan diri untuk pelaksanaan 
perencanaan masa yang akan datang, sekaligus untuk menghadapi hal-hal yang tidak diinginkan. Dalam Al-Qur'an terdapat ayat-ayat yang secara tidak langsung telah memerintahkan kaum muslimin untuk mempersiapkan hari esok secara lebih baik, diantaranya adalah Al-Qur'an surat An-Nisa' ayat 9, yaitu:

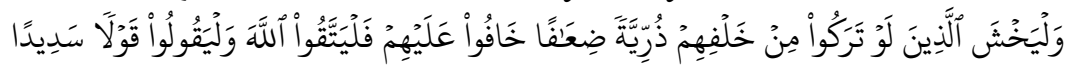

Artinya: "Dan hendaklah takut kepada Allah orang-orang yang seandainya meninggalkan di belakang mereka anak-anak yang lemah, yang mereka khawatir terhadap (kesejahteraan)mereka. Oleh sebab itu, hendaklah mereka bertakwa kepada Allah dan hendaklah mereka mengucapkan perkataan yang benar".

Tabungan mudharabah adalah tabungan yang dijalankan berdasarkan akad mudharabah. Seperti yang telah dikemukakan sebelumnya, mudharabah memiliki dua bentuk, yakni mudharabah mtlaqah dan mudharabah muqayyadah, yang perbedaan utama diantara keduanya terletak pada ada atau tidaknya persyaratan yang diberikan pemilik dana kepada bank dalam mengelola hartanya (Karim 2010, 347). Dalam hal ini, bank syariah bertindak sebagai mudharib (pengelola dana), sedangkan nasabah bertindak sebagai shahibul mal (pemilik dana). Bank syariah dalam kapasitasnya sebagai mudharib, mempunyai kuasa untuk melakukan berbagai macam usaha yang tidak bertentangan dengan prinsip syariah serta mengembangkannya., termasuk melakukan akad mudharabah dengan pihak lain. Namun, di sisi lain, bank syariah juga memiliki sifat sebagai wali amanah (trustee), yang berarti harus berhati-hati atau bijaksana serta beriktikad baik dan bertanggung jawab atas segala sesuatu yang timbul akibat kesalahan atau kelalaiannya.

Dari hasil pengelolaan dana mudharabah, bank syariah akan membagi hasilkan kepada pemilik dana sesuai dengan nisbah yang telah disepakati dan dituangkan dalam akad pembukaan rekening. Dalam mengelola dana tersebut, bank tidak bertanggung jawab terhadap kerugian yang bukan disebabkan oleh kelalaiannya. Namun, apabila terjadi mismanagement (salah urus), bank bertanggung jawab penuh terhadap kerugian tersebut.

Dalam mengelola harta mudharabah, bank menutup biaya operasional tabungan dengan menggunakan nisbah keuntungan yang menjadi haknya. Disamping itu, bank tidak diperkenankan mengurangi nisbah keuntungan nasabah penabung tanpa persetujuan yang bersangkutan. Sesuai dengan ketentuan yang berlaku, PPH bagi hasil tabungan mudharabah dibebankan langsung ke rekening tabungan mudharabah pada saat perhitungan bagi hasil.

Bank syariah nantinya akan membayar bagi hasil kepada nasabah setiap akhir bulan, sebesar sesuai dengan nisbah yang telah diperjanjikan pada saat pembukuan rekening tabungan mudharabah. Bagi hasil yang akan diterima nasabah akan selalu berubah pada akhir bulan. Perubahan bagi hasil ini disebabkan karena adanya fluktuasi pendapatan bank syariah dan fluktuasi dana tabungan mudharabah.

Dasar hukum atas produk perbankan syariah berupa tabungan dalam hukum di Indonesia adalah UU No. 10 Tahun 1998 tentang perubahan atas undang-undang nomor 7 tahun 1992 tentang perbankan. Saat ini secara khusus mendasarkan pada Undang-Undang Nomor 21 Tahun 2008 tentang produk perbankan syariah. Tabungan sebagai salah satu produk penghimpunan dana juga mendapatkan dasar hukum dalam PBI No. 9/19/PBI/2007 tentang pelaksanaan prinsip syariah dalam kegiatan penghimpunan dana dan penyaluran dana serta 
pelayanan jasa bank syariah, sebagaimana yang telah diubah dengan PBI No. 10/16/PBI/2008. Pasal 3 PBI dimaksud menyebutkan antara lain bahwa pemenuhan prinsip syariah dilakukan melalui kegiatan penghimpunan dana dengan mempergunakan akad mudharabah. Sebelum keluarnya PBI tersebut, tabungan sebagai produk perbankan syariah telah mendapatkan pengaturan dalam fatwa DSN No. 02/DSN-MUI/IV/2000 tanggal 12 Mei 2000 yang intinya menyatakan bahwa untuk memenuhi kebutuhan masyarakat dalam meningkatkan kesejahteraan dan dalam menyimpan kekayaan, memerlukan jasa perbankan, salah satu produk perbankan di bidang penghimpunan dana yang penarikannyahanya dapat dilakukan menurut syarat-syarat tertentu yang telah disepakati, tetapi tidak dapat ditarik dengan cek, bilyet, giro, dan atau alat lainnya yang dipersamakan dengan itu.

Para ulama menyatakan, dalam kenyataan banyak orang yang mempunyai kepandaian dalam usaha memproduktifikannya, sementara itu, tidak sedikit pula orang yang tidak memiliki harta namun ia mempun yai kemampuan dalam memproduktifkannya. Oleh karena itu, diperlukan adanya kerjasama di antara kedua pihak tersebut.

\section{METODE PENELITIAN}

Penelitian ini adalah penelitian kuantitatif dengan data time series. Data yang digunakan pada penelitian ini adalah data sekunder. Populasi dalam penelitian ini bank syariah di Indonesia berjumlah total 34 bank syariah, yang terdiri dari 12 Bank Umum Syariah (BUS) dan 22 Unit Usaha Syariah (UUS). Dalam penelitian ini populasi dijadikan sekaligus sebagai sampel. Metode penentuan sampel yang digunakan dalam penelitian ini adalah Purposive Sample. Teknik pengumpulan data yang digunakan adalah metode dokumentasi dan studi pustaka. Variabel dalam penelitian ini adalah Tabungan Mudharabah, Inflasi, Kurs dan BI Rate. Teknik analisis data yang digunakan dalam penelitian ini adalah analisis regresi berganda.

\section{HASIL DAN PEMBAHASAN PENELITIAN}

\section{Perkembangan Tabungan Mudharabah}

Tabungan mudharabah merupakan salah satu jenis simpanan pada bank syariah yang mempengaruhi besarnya total Dana Pihak Ketiga Syariah. Hal ini dimungkinkan karena tabungan sebagai salah satu komponen yang paling banyak digunakan oleh masyarakat. Berdasarkan data, perkembangan tabungan mudharabah periode Juni 2012 sampai dengan Juni 2015 dapat dilihat pada Gambar 1. 


\section{Gambar 1 Perkembangan Tabungan Mudharabah TABUNGAN MUDHARABAH}

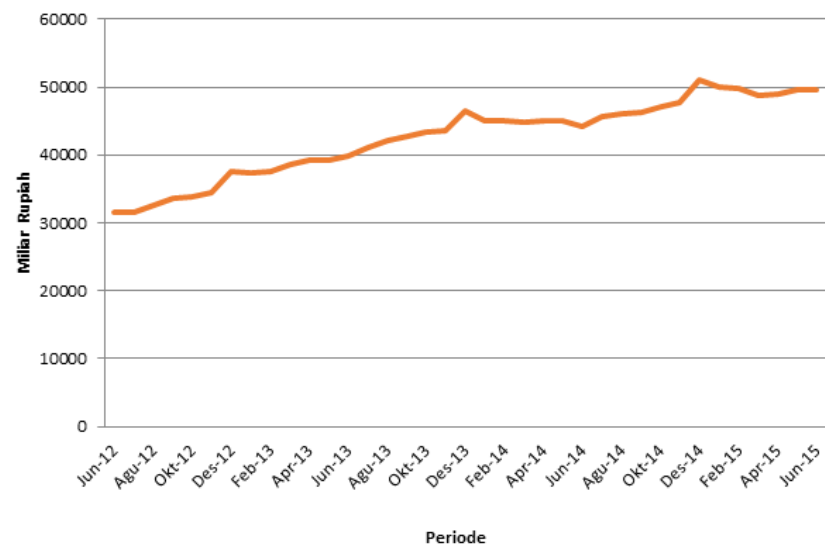

Sumber: Otoritas Jasa Keuangan (diolah)

Sesuai dengan Gambar 1 diketahui bahwa tabungan mudharabah tertinggi berada pada bulan Desember 2014 sebesar Rp. 51.020 milyar dan terendah terjadi pada bulan Juni 2012 sebesar Rp. 31.466 milyar. Selama periode perkembangannya, tabungan mudharabah cenderung meningkat setiap bulannya meskipun sempat mengalami penurunan pada bulan-bulan tertentu.

\section{Perkembangan Inflasi}

Inflasi merupakan salah satu variabel makro yang sangat berpengaruh dan menjadi masalah bagi perekonomian suatu negara. Inflasi yang mengalami kenaikan terus-menerus akan menyebabkan ketidakstabilan yang akan memperburuk kinerja perekonomian suatu negara. Berdasarkan data yang diperoleh, perkembangan inflasi periode Juni 2012 sampai Juni 2015 dapat dilihat pada Gambar 2.

\section{Gambar 2 Perkembangan Inflasi INFLASI}

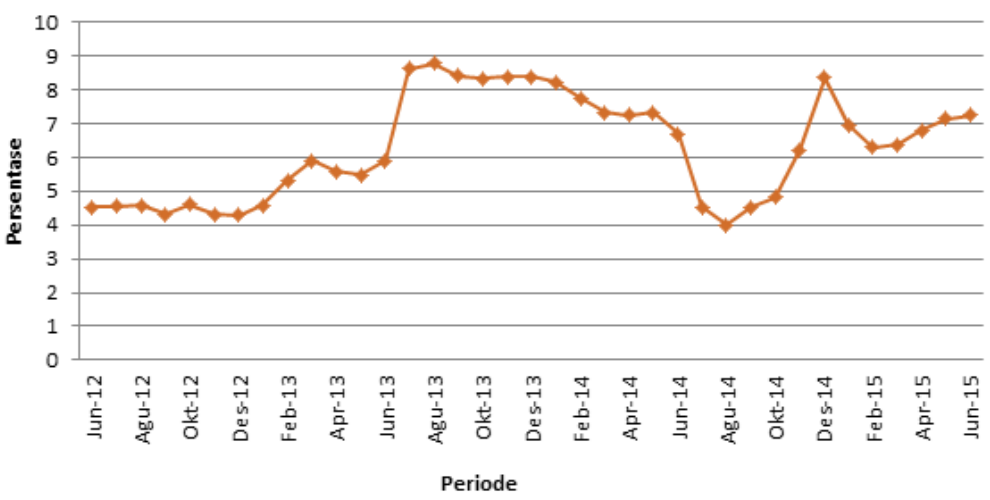

Sumber: Bank Indonesia (diolah)

Berdasarkan Gambar 2 dapat diketahui bahwa perkembangan inflasi tertinggi terjadi pada bulan Agustus 2013 sebesar 8,79 \% dan inflasi terendah terjadi di bulan Agustus 2014 sebesar 3,99 \%. Secara keseluruhan inflasi mengalami fluktuasi dan cendering mengalami kenaikan dari setiap tahunnya. 


\section{Perkembangan Nilai Tukar (Kurs)}

Data Nilai Tukar Rupiah yang digunakan dalam penelitian ini adalah antara harga jual dan harga beli dollar AS yang dinyatakan dalam satuan unit rupiah. Berdasarkan data yang digunakan dari bulan Juni 2012 sampai dengan Juni 2015 maka dapat dilihat pada Gambar 3.

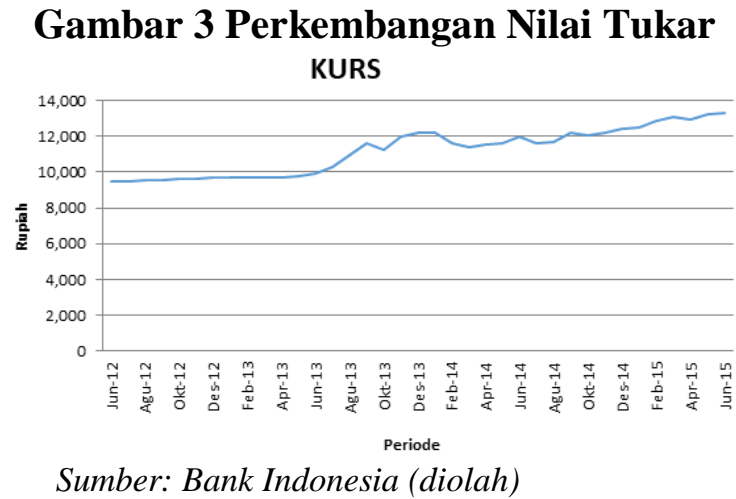

Sesuai dengan Gambar 3 dapat diketahui bahwa perkembangan kurs tertinggi terjadi pada bulan Juni 2015 sebesar Rp.13.332 dan terendah terjadi di bulan Juni 2012 sebesar Rp. 9.480. Sejak tahun 2012 rupiah cenderung bergerak melemah.

\section{Perkembangan BI rate}

$\mathrm{BI}$ rate yang digunakan dalam bentuk persentase, berdasarkan data perkembangan BI rate periode Juni 2012 sampai dengan Juni 2015 yang diperoleh, maka dapat dilihat pada Gambar 4.

\section{Gambar 4 Perkembangan BI Rate}

BI RATE

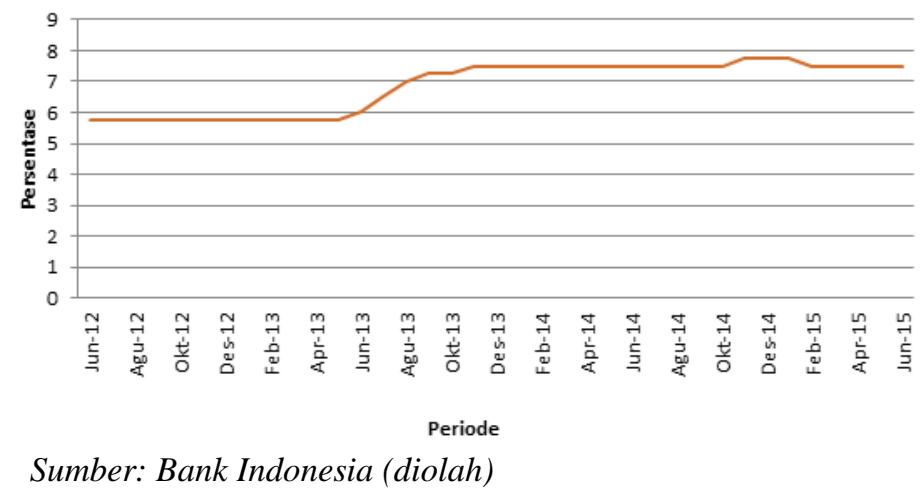

Berdasarkan Gambar 4 dapat diketahui bahwa perkembangan BI rate tertinggi terjadi pada bulan November 2014 sampai Febuari 2015 sebesar 7,75\% dan terendah terjadi di bulan Juni 2012 sampai dengan Mei 2013 sebesar 5,75 \%.

Semua data yang digunakan dalam analisis ini merupakan data sekunder deret waktu (time series) mulai dari Juni 2012 sampai Juni 2015. Hasil pengolahan data ini menggunakan regresi linier berganda dengan metode OLS (Ordinary Least Square). Berikut ini adalah hasil pengolahan data menggunakan regresi berganda dengan metode OLS (Ordinary Least Square). 


\section{Uji Normalitas}

\section{Gambar 5 Hasil Uji Normalitas}

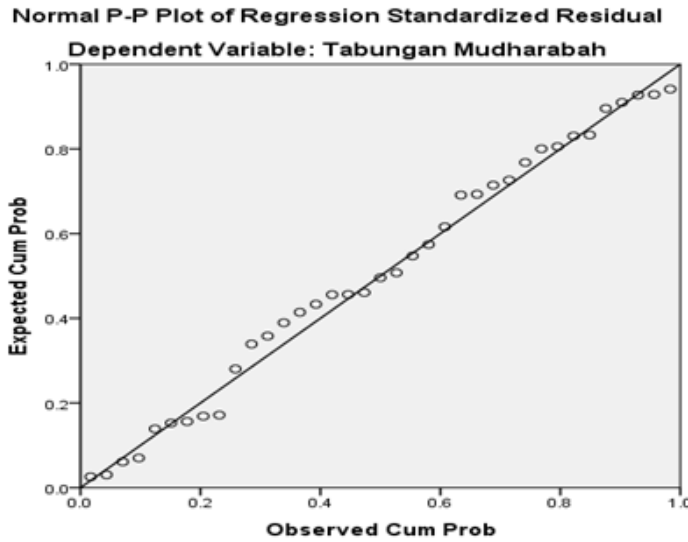

Sumber: Outpus SPSS

Uji normalitas data dilakukan untuk mengetahui bahwa residual berdistribusi normal atau tidak normal. Berdasarkan Gambar 5 diketahui bahwa data atau titik-titik menyebar disekitar garis diagonal (tidak terpencar jauh dari garis lurus), maka dapat dikatakan bahwa data variabel memiliki residual yang berdistribusi normal. Dengan demikian asumsi yang menyatakan bahwa model regresi harus memiliki residual berdistribusi normal dapat dipenuhi.

\section{Uji Heterokedastisitas}

\section{Gambar 6 Hasil Uji Heterokedastisitas}

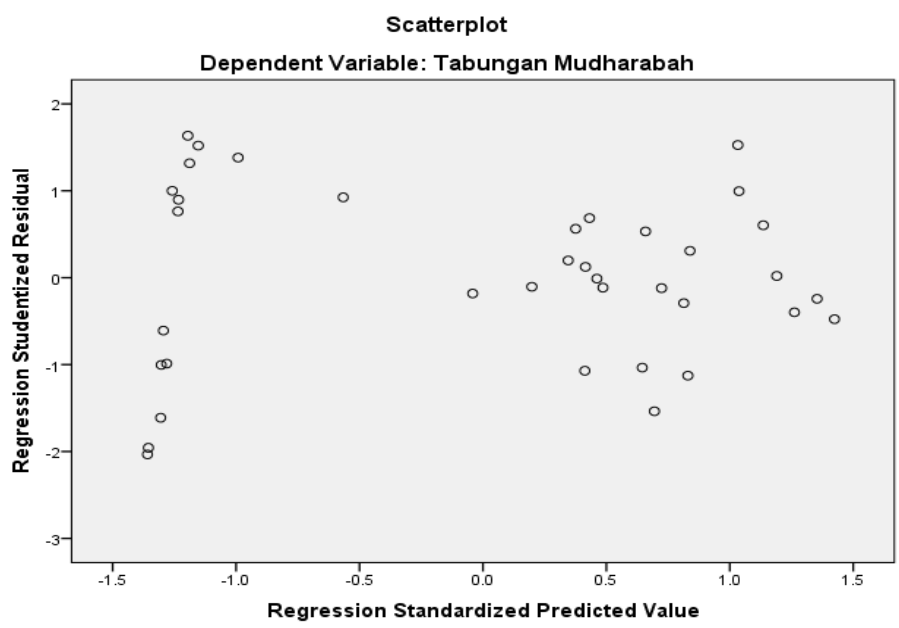

Sumber: Output SPSS

Uji heteroskedastisitas bertujuan menguji model regresi yang menunjukkan ada tidaknya kesamaan varians dari satu residual pengamatan ke pengamatan yang lain. Berdasarkan Gambar 6 terlihat bahwa titik-titik menyebar secara acak serta tersebar baik di atas maupun di bawah angka 0 pada sumbu Y. Dengan demikian dapat dikatakan tidak terjadi heteroskedastisitas pada model 
regresi. Dengan demikian asumsi yang menyatakan bahwa dalam model regresi tidak terjadi heteroskedastisitas dapat dipenuhi.

\section{Uji Multikolinearitas}

Uji multikolinieritas bertujuan untuk menguji apakah model regresi ditemukan adanya korelasi antar variabel bebas. Model regresi yang baik seharusnya tidak terjadi korelasi di antara variabel bebas.

Tabel 1 Hasi Uji Multikolininieritas

\begin{tabular}{|c|c|c|c|}
\hline & \multirow{2}{*}{ Model } & \multicolumn{2}{|c|}{ Collinearity Statistics } \\
\hline & & Tolerance & VIF \\
\hline \multirow{3}{*}{1} & Inflasi & ,660 & 8,515 \\
\hline & Kurs Rupiah &, 524 & 8,055 \\
\hline & BI Rate & ,512 & 8,919 \\
\hline
\end{tabular}

Berdasarkan Tabel 1 dapat diketahui bahwa nilai tolerance menunjukkan tidak ada variabel bebas yang memiliki nilai tolerance kurang dari 0,10 . Nilai tolerance variabel inflasi sebesar 0,660, nilai tolerance variabel kurs rupiah sebesar 0,524 dan nilai tolerance variabel BI Rate sebesar 0,512. Demikian juga nilai VIF untuk variabel bebas tidak ada yang memiliki nilai lebih dari 10 , nilai VIF variabel inflasi sebesar 8,515, dan nilai VIF variabel kurs rupiah sebesar 8,055 nilai VIF variabel BI Rate sebesar 8,919. Dengan demikian, dapat dikatakan bahwa dalam model regresi antara variabel bebas inflasi $\left(\mathrm{X}_{1}\right)$, Kurs $\mathrm{Rp}\left(\mathrm{X}_{2}\right)$ dan BI Rate $\left(\mathrm{X}_{3}\right)$ tidak terjadi multikolonieritas.

\section{Uji Autokorelasi}

Tabel 2 Uji Durbin-Watson

\begin{tabular}{lccc}
\hline Model & $\boldsymbol{R}$ & $\boldsymbol{R}$ Square & Durbin-Watson \\
\hline 1 &, $946^{\mathrm{a}}$ &, 895 & 1,554 \\
\hline $\begin{array}{l}\text { a. Predictors: (Constant), BI Rate, Inflasi, Kurs Rp } \\
\text { b. Dependent Variable: Tabungan Mudharabah }\end{array}$
\end{tabular}

Sumber: Output SPSS

Autokorelasi adalah suatu keadaan dimana terjadi korelasi antara residual tahun ini dengan tingkat kesalahan tahun sebelumnya. Berdasarkan hasil penghitungan pada Tabel 2, diketahui nilai Durbin-Watson $(D W)$ sebesar 1,554. Oleh karena nilai DW besar dari 1 dan lebih kecil dari $3(1<1,554<3)$, maka tidak ada autokorelasi. Dengan demikian, dapat dikatakan bahwa dalam model regresi tidak terjadi autokorelasi.

\section{Uji Linearitas}

Tujuan dilakukan uji linieritas adalah untuk mengetahui apakah antara variabel terikat $(\mathrm{Y})$ dan variabel bebas $(\mathrm{X})$ mempunyai hubungan linier. 


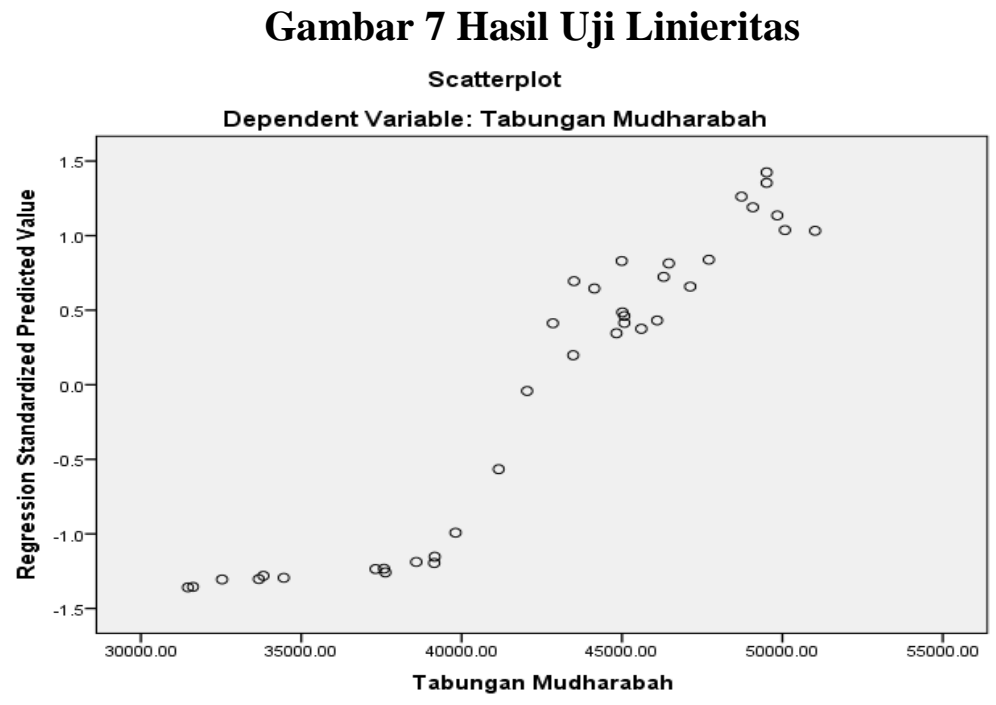

Sumber: Output SPSS

Berdasarkan Gambar 7 terlihat sebaran data membentuk arah garis lurus dari kiri bawah ke kanan atas. Dengan demikian dapat dikatakan bahwa model regresi mempunyai bentuk yang linier. Oleh karena itu asumsi model regresi harus linier sudah terpenuhi.

\section{Analisis Regresi Berganda}

Tabel 3 Hasil Koefisien Regresi Berganda

\begin{tabular}{|c|c|c|c|c|c|c|}
\hline & \multirow[t]{2}{*}{ Model } & \multicolumn{2}{|c|}{$\begin{array}{l}\text { Unstandardized } \\
\text { Coefficients }\end{array}$} & \multirow{2}{*}{$\begin{array}{c}\text { Standardized } \\
\text { Coefficients } \\
\text { Beta }\end{array}$} & \multirow[t]{2}{*}{$t$} & \multirow[t]{2}{*}{ Sig. } \\
\hline & & $\boldsymbol{B}$ & Std. Error & & & \\
\hline \multirow{4}{*}{1} & (Constant) & $-4022,021$ & 2813,933 & & $-1,429$ & , 162 \\
\hline & Inflasi & 145,198 & 254,831 & , 139 & 3,570 & ,003 \\
\hline & Kurs Rp & 3,036 & ,707 & 686 & 4,295 & ,000 \\
\hline & BI Rate & 1706,790 & 1148,103 &, 250 & 3,487 &, 007 \\
\hline
\end{tabular}

Sumber: Output SPSS

Berdasarkan Tabel 3 didapat model persamaan regresi berganda sebagai berikut: $\mathrm{Y}=-4022,021+145,198 \mathrm{X}_{1}+3,036 \mathrm{X}_{2}+1706,790 \mathrm{X}_{3}$. Nilainilai hasil regresi berganda tersebut dapat dijelaskan sebagai berikut: a) Nilai konstan (a) $=-4022,021$. Artinya bahwa besarnya nilai prediksi (Y) sebesar 4022,021 jika variabel bebas (independent) $\mathrm{X}_{1}, \mathrm{X}_{2}$ dan $\mathrm{X}_{3}=0$. Hal ini berarti bahwa, jika tidak dipengaruhi inflasi, kurs Rp dan BI Rate, maka nilai prediksi tabungan mudharabah sebesar $\mathrm{X}_{2}$. b) Nilai koefisien regresi inflasi $\left(\mathrm{X}_{1}\right)$ positif sebesar 145,198. Artinya, jika koefisien inflasi $\left(X_{1}\right)$ berubah satu satuan, maka tabungan mudharabah (Y) akan berubah sebesar 145,198 kali satuan dengan asumsi bahwa variabel lainnya tetap atau konstan. c) Nilai koefisien regresi kurs $\mathrm{Rp}\left(\mathrm{X}_{2}\right)$ positif sebesar 3,036. Artinya, jika koefisien regresi kurs $\mathrm{Rp}\left(\mathrm{X}_{2}\right)$ berubah satu satuan, maka tabungan mudharabah (Y) akan berubah sebesar 3,036 kali satuan dengan asumsi bahwa variabel lainnya tetap atau konstan. D) Nilai koefisien regresi BI Rate $\left(\mathrm{X}_{3}\right)$ positif sebesar 1706,790. Artinya, jika koefisien 
regresi BI Rate $\left(\mathrm{X}_{3}\right)$ berubah satu satuan, maka tabungan mudharabah (Y) akan berubah sebesar 1706,790 kali satuan dengan asumsi bahwa variabel lainnya tetap atau konstan.

\section{Uji Parsial (Uji t)}

Uji t bertujuan untuk mengetahui pengaruh secara parsial antara variabel bebas terhadap variable terikat (dependent). Kriteria pengujian adalah jika nilai $t_{\text {hitung }}>t_{\text {tabel }}$ atau nilai Signifikansi $<0,05$ berarti $\mathrm{H}_{1}$ diterima, sebaliknya ditolak. Dengan nilai $\alpha=0,05$ dan $\mathrm{n}=37$ maka nilai $\mathrm{t}_{\text {tabel }}=\mathrm{n}-\mathrm{k}-1=37-1-1=35$ adalah sebesar 2,021.

Pada Tabel 3, kolom t didapat nilai $t_{\text {hitung }}$ sebesar 3,570 dan nilai kolom sig didapat nilai sig sebesar 0,003 untuk Inflasi. Oleh karena nilai $t_{\text {hitung }}>t_{\text {tabel }}$ atau $3,570>2,021$ serta nilai $0,003<0,05, \mathrm{H}_{1}$ diterima. Hal ini menyatakan bahwa secara statistik terbukti inflasi berpengaruh terhadap tabungan mudharabah pada perbankan syariah. Nilai Beta, sebesar 0.139, ini menunjukkan bahwa inflasi berpengaruh positif terhadap tabungan mudharabah pada perbankan syariah. Nilai positif berarti jika ada pengaruh-pengaruh positif dari inflasi, maka akan meningkatkan tabungan mudharabah pada perbankan syariah.

Pada Tabel 3, kolom $t$ didapat nilai $t_{\text {hitung }}$ sebesar 4,295 dan nilai kolom sig didapat nila sig sebesar 0,000 untuk kurs rupiah. Oleh karena nilai $t_{\text {hitung }}>t_{\text {tabel }}$ atau 4,295 $>2,021$ serta nilai $0,000<0,05$, berarti $\mathrm{H}_{1}$ diterima. Hal ini menyatakan bahwa secara statistik terbukti kurs rupiah berpengaruh terhadap tabungan mudharabah pada perbankan syariah. Nilai Beta, sebesar 0,86 , ini menunjukkan bahwa kurs rupiah berpengaruh positif terhadap tabungan mudharabah pada perbankan syariah. Nilai positif berarti jika ada pengaruhpengaruh positif dari kurs rupiah, maka akan meningkatkan tabungan mudharabah pada perbankan syariah.

Pada Tabel 3, kolom t didapat nilai $t_{\text {hitung }}$ sebesar 3,487 dan nilai kolom sig didapat nila sig sebesar 0,007 untuk BI Rate. Oleh karena nilai $t_{\text {hitung }}>t_{\text {tabel }}$ atau $3,487>2,021$ serta nilai $0,007<0,05, \mathrm{H}_{1}$ diterima. Hal ini menyatakan bahwa secara statistik terbukti BI rate berpengaruh terhadap tabungan mudharabah pada perbankan syariah. Nilai Beta, sebesar 0,259. Nilai ini menunjukkan bahwa BI rate berpengaruh positif terhadap tabungan mudharabah pada perbankan syariah. Nilai positif berarti jika ada pengaruh-pengaruh positif dari BI rate, maka akan meningkatkan tabungan mudharabah pada perbankan syariah.

Besar nilai Beta inflasi terhadap tabungan mudharabah pada perbankan syariah adalah sebesar 0,139, besar nilai Beta kurs rupiah terhadap tabungan mudharabah pada perbankan syariah adalah sebesar 0,686 dan besar nilai Beta BI rate terhadap tabungan mudharabah pada perbankan syariah adalah sebesar 0,250. Nilai kurs rupiah 0,686 > dari nilai inflasi 0,139 dan nilai BI rate 0,250. Dengan kata lain, variabel yang paling berpengaruh terhadap tabungan mudharabah pada perbankan syariah adalah kurs rupiah. 


\section{Uji Simultan}

Tabel 4 ANOVA

\begin{tabular}{|c|c|c|c|c|c|}
\hline Model & Sum of Squares & $d f$ & Mean Square & $\boldsymbol{F}$ & Sig. \\
\hline 1 Regression & 1056635186,998 & 3 & 352211728,999 & 94,131 &, $000^{\mathrm{b}}$ \\
\hline Residual & 123476569,975 & 33 & 3741714,242 & & \\
\hline Total & 1180111756,973 & 36 & & & \\
\hline
\end{tabular}

Berdasarkan Tabel 4, diperoleh $\mathrm{F}_{\text {hitung }}$ sebesar 94,131 dan nilai signifikansi sebesar 0,000. Oleh karena nilai $F_{\text {hitung }}>F_{\text {tabel, }}$, atau 94,131 > 2,89 dan nilai probabilitas (sig) $<0,05$ atau $0,000<0,05$, maka $\mathrm{H}_{1}$ diterima. Hal ini menyatakan bahwa secara statistik terbukti ada pengaruh antara inflasi, kurs rupiah dan BI rate secara simultan terhadap tabungan mudharabah pada perbankan syariah di Indonesia.

\section{Uji Adjusted $\mathbf{R}^{2}$ (Koefesien Determinasi)}

Pengujian koefisien determinasi dilakukan untuk mengetahui seberapa besar kemampuan variabel independen dalam menjelaskan variabel dependen. Berdasarkan pengolahan statistik dengan program IBM SPSS Statistics Version 23 diperoleh hasil hubungan variabel bebas secara bersama-sama (simultan) dengan variabel terikat sebagai berikut:

Tabel 5 Model Summary

\begin{tabular}{lcccc}
\hline Model & $\boldsymbol{R}$ & $\boldsymbol{R}$ Square & Adjusted R Square & Std. Error of the Estimate \\
\hline 1 &, $946^{\mathrm{a}}$ &, 895 &, 886 & 1934,35112 \\
\hline a. Predictors: (Constant), BI Rate, Inflasi, Kurs Rp & & \\
b. Dependent Variabel: Tabungan Mudharabah & & \\
Sumber: Output SPSS &
\end{tabular}

Berdasarkan Tabel 5, dapat diketahui bahwa $\mathrm{R}$ sebesar 0.946 menunjukkan bahwa korelasi antara inflasi, kurs RP dan BI rate secara bersama-sama (multi korelasi) dengan tabungan mudharabah pada perbankan syariah adalah sangat kuat. $\mathrm{R}$ Square sebesar 0,895 menunjukkan bahwa $89.5 \%$ dari variasi tabungan mudharabah pada perbankan syariah dapat dijelaskan oleh inflasi, kurs RP dan BI rate atau besar kontribusi variabel inflasi, kurs RP dan BI rate secara bersamasama terhadap tabungan mudharabah pada perbankan syariah sebesar $89,5 \%$, sedangkan sisanya $10.5 \%$ adalah kontribusi variabel lain.

\section{KESIMPULAN}

Inflasi secara parsial berpengaruh positif terhadap tabungan mudharabah. Kurs rupiah secara parsial berpengaruh positif tabungan mudharabah. BI rate secara parsial berpengaruh positif terhadap tabungan mudharabah. Inflasi, nilai tukar (kurs) dan BI Rate secara simultan mempunyai pengaruh signifikan terhadap tabungan mudharabah. Dengan adanya kenaikan tabungan mudharabah yang 
disebabkan adanya inflasi, maka bagi kalangan perbankan syariah lebih menyukai terjadinya inflasi (inflasi rendah). Bagi kalangan perbankan syariah, lebih menyukai ketika BI Rate rendah karena hal ini akan meningkatkan tabungan mudharabah.

Untuk penelitian lanjutan agar dapat memperpanjang periode waktu penelitian serta menggunakan lebih banyak variabel yang mempengaruhi tabungan mudharabah, sehingga dapat memberikan hasil penelitian yang lebih akurat dan baik. Tabungan mudharabah tidak hanya dipengaruhi oleh motif ekonomi saja seperti inflasi, nilai tukar, dan BI rate, tetapi juga dipengaruhi oleh faktor lain seperti tingkat religiusitas, reputasi dan kepercayaan masyarakat terhadap Bank Syariah.

\section{DAFTAR PUSTAKA}

Al-Arif, M. Nur Rianto. 2010. Teori Makroekonomi Islam: Konsep, Teori dan Analisis. Bandung: Alphabeta.

Ariestya, Dian. 2011. Analisis Pengaruh Imbal Bagi Hasil, Jumlah Kantor Cabang, Suku Bunga, Kurs dan SWBI terhadap Jumlah Tabungan Mudharabah. Jakarta.

Bahri, Saipul. 2016. Untuk Menggapai Karunia Tuhanmu. Yogyakarta: Deepublish.

Hermansyah. 2011. Hukum Perbankan Nasional Indonesia. Jakarta: Kencana.

Ismail. 2011. Perbankan Syariah. Jakarta: Kencana.

Karim, Adiwarman A. 2010. Bank Islam: Analisis Fiqih dan Keuangan. Jakarta: PT. Raja Grafindo Persada.

Karim, Adiwarman A. 2014. Ekonomi Makro Islami. Jakarta: Rajawali Pers.

Misbahuddin dan Iqbah Hasan. 2013. Analisis Data Penelitian Dengan Statistik. Jakarta: PT Bumi Aksara.

Muhammad. 2014. Manajemen Dana Bank Syariah. Jakarta: Rajawali Pers.

Nasution, Mustasfa Edwin dkk. 2010. Pengenalan Eksklusif: Ekonomi Islam. Jakarta: Kencana.

Rahardja, Prathama. 2008. Pengantar Ilmu Ekonomi (Mikroekonomi dan Makroekonomi). Jakarta: Lembaga Penerbit Fakultas Ekonomi Universitas Indonesia.

Siregar, Sofyan. 2013. Metode Penelitian Kuantitatif. Jakarta: Kencana.

Siregar, Sofyan. 2015. Statistik Parametrik Untuk Penelitian Kuantitatif. Jakarta: PT. Bumi Aksara.

Suharyanti, ST. 2010. “Analisis Pengaruh Nisbah Bagi Hasil, Inflasi, Pendapatan Nasional/PDB, dan SWBI Terhadap Tabungan Mudharabah Pada Perbankan Syariah Di Indonesia". Jurnal Ilmu Ekonomi dan Studi Pembangunan.

Sujarweni, V. Wiratna. 2015. Statistik Untuk Bisnis dan Ekonomi. Yogyakarta: Pustaka Baru Press.

Sukirno, Sadono. 2011. Makroekonomi Teori Pengantar. Jakarta: PT Raja Grafindo Persada.

Supriyono, Maryanto. 2011. Buku Pintar Perbankan. Yogyakarta: Andi.

Wahana Komputer. 2012. 10 Model Penelitian dan Pengolahannya Dengan SPSS 14, Edisi IV. Yogyakarta: Andi. 